DOI: $10.29202 /$ nvngu/2019-3/4

F. Ait Merzeg ${ }^{1,2}$, N. Bezzi ${ }^{1}$, Dr. Sc. (Tech.), Prof.
1 - Laboratory of Materials Technology and Process Engineering, Abderahmane Mira University, Bejaia, Algeria

2 - Unit on Analyses and Technological Development in Environment, Scientific and Technical Research Centre in Physico-Chemical Analyses BP 384, Bou-Ismail, Algeria

\title{
OPTIMISATION OF THE FLOTATION PARAMETERS ON THE ENRICHMENT OF PHOSPHATE ORE (ALGERIA)
}

Purpose. Treatment of the Algerian natural phosphate ore from the Jebel Onk deposit by flotation process with the use of flotation cell of the Motso Mineral Industries type (Inc. Darville, PA USA). This phosphate ore has a carbonate and silicate gangue, which negatively affects viscosity in the production of phosphoric acid.

Methodology. The experimental procedure used is based on two aspects: 1) a prior mechanical preparation of all the processes: crushing, homogenization, quartering, sieving, followed by attrition and desliming operations; 2) a preparation of reagents of different qualities followed by pulping, packaging and flotation.

Findings. We can conclude that the reverse flotation is perfectly favorable and presents an excellent economic yield. The flotation process has shown its efficiency in depressed phosphatic elements in the phosphate concentrates (flowings) as well as in floated carbonates in the carbonated wastes (floatings). Indeed, it was possible to attain the phosphate concentrate contents of nearly $31 \%$ in $\mathrm{P}_{2} \mathrm{O}_{5}$ with a satisfactory recovery (85-95\%).

Originality. Flotation tests are applied for both granulometric classes $\mathrm{C} 1(40-250 \mu \mathrm{m})$ and $\mathrm{C} 2(250-500 \mu \mathrm{m})$ treating a little more than $30 \%$ of $\mathrm{P}_{2} \mathrm{O}_{5}$ with respect to raw sample (26\%), which allowed achieving satisfactory yields ( 85 to $95 \%$ ). The best yields were obtained under the following optimal conditions: the conditioning and flotation optimal time periods recorded for both classes are 10 and $8 \mathrm{~min}$ for class $\mathrm{C} 1$, whereas for class $\mathrm{C} 2$ they were found to be $7.5 \mathrm{~min}$ and $6 \mathrm{~min}$, respectively. The best $\mathrm{pH}$ that corresponds to a higher flotation recovery for both classes is 9 . The oleic acid adsorption optimal dosages on the gangue elements are 2500 and $2000 \mathrm{~g} / \mathrm{t}$ for class $\mathrm{C} 1$ and $\mathrm{C} 2$, respectively.

Practical value. Different analytical techniques (XRD, XRF, FTIR) were applied for the flotation products namely: the flowings (phosphate concentrate) and the floatings (carbonated waste), which allows a new approach in the optimization of exploitation and valorization of the phosphate ores, as well as the focus of organizational chart of the treatment, aiming to provide the best quality of the phosphate concentrate.

Keywords: Natural phosphate, carbonates, flotation, optimization, Jebel Onk

Introduction. The deposits of Algerian natural phosphate ores are located in the Djebel Onk region situated near the Algerian-Tunisian border. These phosphates are agglomerates of apatitic phosphatic elements cemented by a mixture of dolomite with a dominant proportion and low proportion of quartz, clay and calcite [1]. Phosphate ore is the primary natural resource from which phosphorous is extracted, while apatite is the most prevalent phosphate [2]. Phosphate ores are vital nonrenewable resources and essential components in agricultural fertilizers and phosphorous-based chemicals [3]. The phosphate ore is an important non-renewable resource and is an irreplaceable raw material for phosphorus-based fertilizers and chemicals [4]. Several techniques of treatments were used for enrichment of these phosphate ores: calcination, fragmentation, granulometric separations, and others.

In our study we were interested in a very well-known techno-economic technique for this flotation ore type. It relies on the flotation of gangue elements (carbonates, silicates) by a collector and the depression of apatitic phosphatic elements. Many parameters influence the flotation recovery including reactants dosage (collector, depressing, activating and foaming), $\mathrm{pH}$, solid proportion, conditioning and flotation time, stirring speed, air bubble size, particle size, and others.

(C) Ait Merzeg F., Bezzi N., 2019
The objective is to propose a scheme of separation of carbonate-phosphate system using both granulometric classes with the optimization of the main experimental parameters. This study is preceded by physico-chemical and mineralogical characterizations to define the optimal release mesh of phosphatic elements and carbonates.

Experimental. Preparation of sample. The phosphate samples destined for flotation tests are prepared previously in three steps: mechanical, putting in pulp, attrition and degumming.

Step 1: The crude phosphate ores are submitted to a mechanical operations series: crushing, homogenization, quartering and sieving in a way to obtain the following dimensions: fine particles $<40 \mu \mathrm{m}$, class $\mathrm{C} 1$ $(40-250 \mu \mathrm{m})$, class $\mathrm{C} 2(250-500 \mu \mathrm{m})$ and coarse particles $>500 \mu \mathrm{m}$. The classes $\mathrm{C} 1$ and $\mathrm{C} 2$ are considered as the recoverable classes by the flotation process, while the fine and coarse particles are rich in siliceous and dolomitic materials, and considered as sterile waste.

Step2: The pulping in pulp which consists of dispersing the solid particles $\mathrm{C} 1$ and $\mathrm{C} 2$ in water with a mass ratio of $25 \%$ of solid. These samples are submitted to attrition with a stirring speed of 1100 and $1200 \mathrm{rpm}$ during a time period of 30 and $15 \mathrm{~min}$ for classes $\mathrm{C} 1$ and $\mathrm{C} 2$, respectively.

Step3: The obtained products in the previous step are carefully sifted by wet in a way to eliminate the clayey 
and siliceous coatings of the phosphate grains that influence directly the elevated consumption of the collector required for flotation [5].

Reverse flotation process. The study was realized for both classes $\mathrm{C} 1$ (24.77 in $\mathrm{P}_{2} \mathrm{O}_{5}$ ) and $\mathrm{C} 2$ (27.83 in $\mathrm{P}_{2} \mathrm{O}_{5}$ ) treated by reverse flotation in flotation cell by Motso Mineral Industries (Inc. Darville, PA USA), which is constituted of a tank contained with an agitation axis on which a propeller is affixed.

Conditioning of the flotation is done in a pulp of $25 \%$ of solid by adding the flotation reagents at room temperature. After conditioning, the suspension is introduced into the flotation cell which is fed with air from bottom. The phosphatic elements are depressed with double tartrate of sodium and potassium by operating at basic $\mathrm{pH}$ and the gangue elements (carbonates) are floated with the oleic acid collector in the presence of ethanol modulated with phosphoric acid [6, 7]. The alkalinity of the pulp is maintained by addition of lime to a lesser extent of sodium hydroxide [8]. In mineral processing, solid particles - which can be easily wetted with water - are called hydrophilic, while particles with limited affinity for wetting are called hydrophobic [9].

The lowering of $\mathrm{pH}$ can be attained by the addition of phosphoric acid. These chemicals are often used in very significant amounts in almost all flotation operations. Foam charged of carbonates is recovered by overflowing at the cell top. The obtained products, floating and flowing, constitute the carbonated waste and phosphate concentrate respectively (Fig. 1).

Chemical analysis and evaluation of the flotation products. The evaluation of chemical composition of the sample was done through X-ray fluorescence. The quality of the floated product was evaluated by means of the content and recovery of $\mathrm{P}_{2} \mathrm{O}_{5}$ in the flotation products. The recovery of each chemical species $(\mathrm{Re})$ in the samples was calculated in agreement with equation [10].

$$
R e=\frac{M_{F} x_{F}}{M_{A} x_{A}} .100
$$

Results and discussion. Optimization of the main flotation parameters. Conditioning time. Reverse flotation results for both studied classes as well as the weight recovery yields in depressed phosphate and floated carbonates at different conditioning times are shown in Table 1. This latter also represents the $\mathrm{P}_{2} \mathrm{O}_{5}$ content and flotation recovery for flotation products (floating and flowing). We can see in this table that the optimal conditioning time periods recorded for both classes $\mathrm{C} 1$ and $\mathrm{C} 2$ are 10 and $7.5 \mathrm{~min}$, respectively.

Fig. 2, $a$ shows a remarkable increase in the flotation recovery for class $\mathrm{C} 1$ by increasing conditioning time to reach the maximum at $10 \mathrm{~min}$. There is also a weak reduction for the flotation recovery after $7.5 \mathrm{~min}$ for class C2. Indeed, this difference is due to the mineralogical composition of both classes and consumption of flotation reagents [5]. Class $\mathrm{C} 1$ is rich in carbonates and its specific surface area is higher compared to class C2, so the adsorption time of flotation reagents on carbonates will be greater in class $\mathrm{C} 1$ than in class $\mathrm{C} 2$.

Flotation time. Table 2 summarizes the reverse flotation results for both studied classes as well as the weight recovery yields in depressed phosphate and floated car-

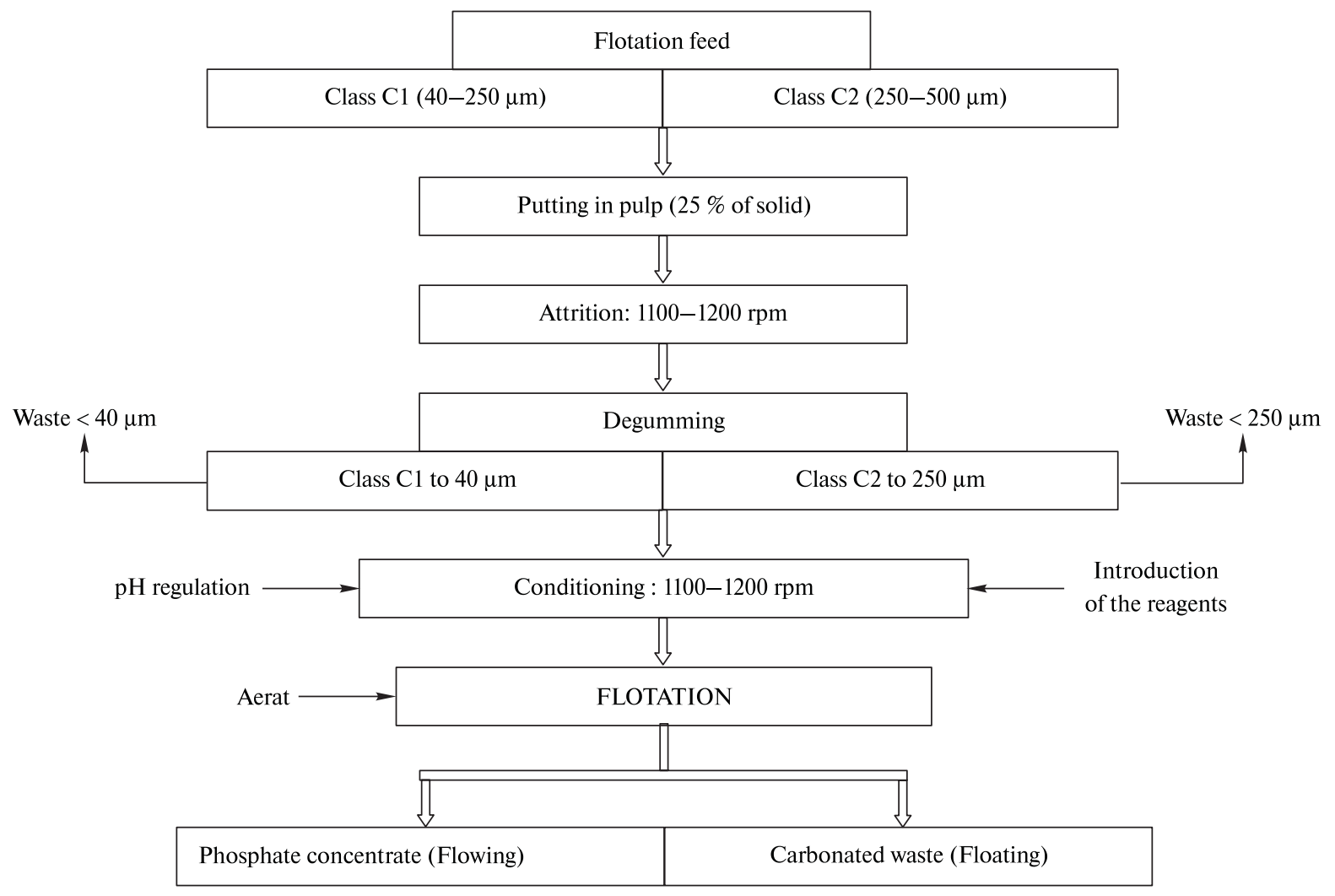

Fig. 1. Reverse flotation experimental protocol of natural phosphate ore of Kef ES Sennoun deposit (Djebel Onk) 
Table 1

Variation of $\mathrm{P}_{2} \mathrm{O}_{5}$ content and flotation recovery $(\mathrm{Re})$ in flotation products of both classes at different conditioning time $(\mathrm{Tc})$

\begin{tabular}{|c|c|c|c|c|c|c|c|c|c|}
\hline \multirow{2}{*}{\multicolumn{2}{|c|}{$\frac{\mathrm{Tc}(\mathrm{min})}{\text { Products }}$}} & \multicolumn{2}{|c|}{2.5} & \multicolumn{2}{|c|}{5.0} & \multicolumn{2}{|c|}{7.5} & \multicolumn{2}{|c|}{10} \\
\hline & & \multirow{2}{*}{$\begin{array}{c}\text { Floating } \\
13.14\end{array}$} & \multirow{2}{*}{$\begin{array}{c}\text { Flowing } \\
86.86\end{array}$} & \multirow{2}{*}{$\begin{array}{c}\text { Floating } \\
14.12\end{array}$} & \multirow{2}{*}{$\begin{array}{c}\text { Flowing } \\
85.88\end{array}$} & \multirow{2}{*}{$\begin{array}{c}\text { Floating } \\
16.20\end{array}$} & \multirow{2}{*}{$\begin{array}{c}\text { Flowing } \\
83.80\end{array}$} & \multirow{2}{*}{$\begin{array}{c}\text { Floating } \\
16.49\end{array}$} & \multirow{2}{*}{$\begin{array}{c}\text { Flowing } \\
83.51\end{array}$} \\
\hline Mass (\%) & $\mathrm{C} 1$ & & & & & & & & \\
\hline & $\mathrm{C} 2$ & 06.02 & 93.98 & 06.12 & 93.88 & 07.82 & 92.18 & 09.48 & 90.52 \\
\hline \multirow[t]{2}{*}{$\mathrm{P}_{2} \mathrm{O}_{5}(\%)$} & $\mathrm{C} 1$ & 24.37 & 24.75 & 23.65 & 26.15 & 21.56 & 28.24 & 18.79 & 28.76 \\
\hline & $\mathrm{C} 2$ & 26.16 & 27.95 & 25.85 & 28.87 & 18.93 & 30.21 & 25.69 & 28.63 \\
\hline \multirow[t]{2}{*}{$\operatorname{Re}(\%)$} & $\mathrm{C} 1$ & \multicolumn{2}{|c|}{87.04} & \multicolumn{2}{|c|}{87.05} & \multicolumn{2}{|c|}{87.15} & \multicolumn{2}{|c|}{88.57} \\
\hline & $\mathrm{C} 2$ & \multicolumn{2}{|c|}{94.36} & \multicolumn{2}{|c|}{94.49} & \multicolumn{2}{|c|}{94.95} & \multicolumn{2}{|c|}{91.40} \\
\hline
\end{tabular}

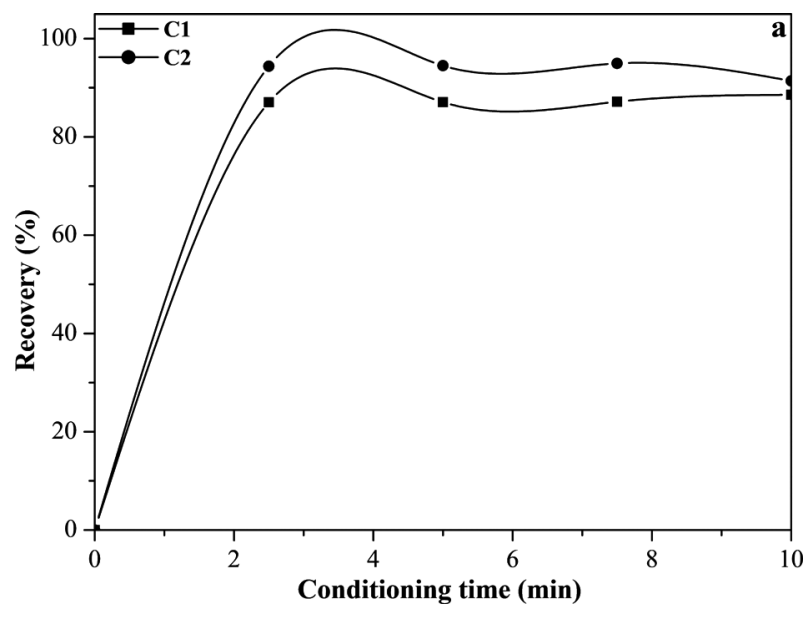

$a$

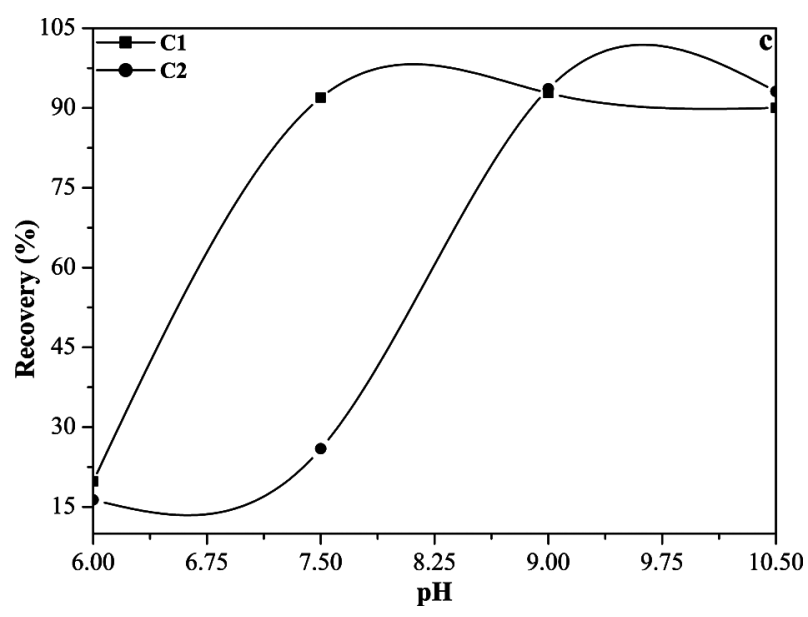

$c$

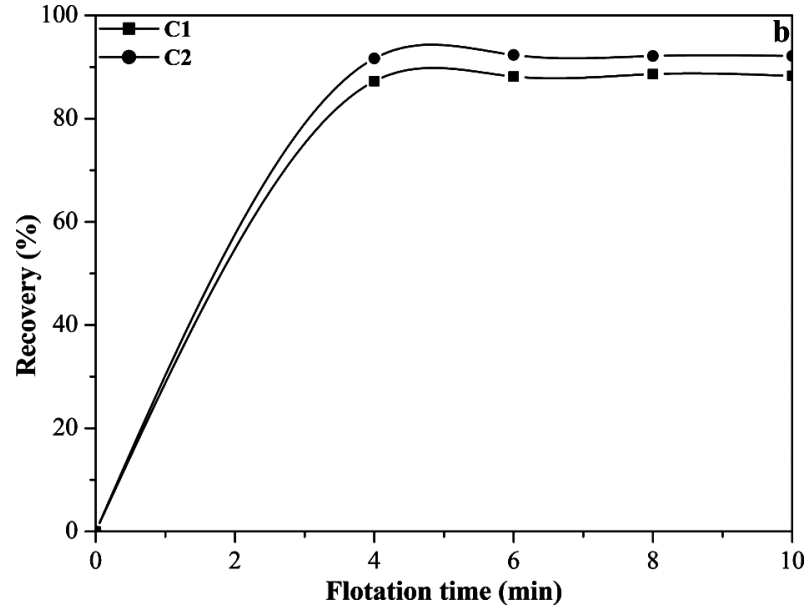

$b$

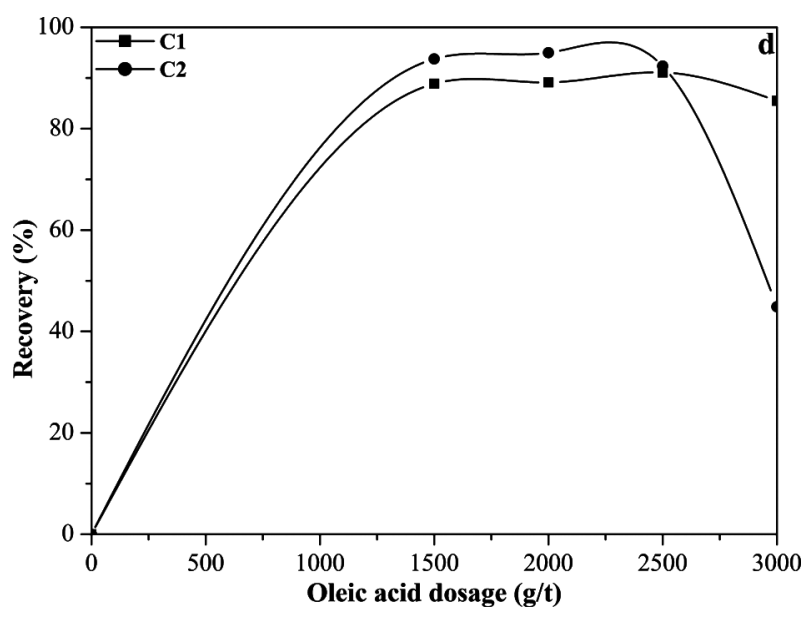

$d$

Fig. 2. Characteristics of the floatation process:

$a$ - variation of flotation recovery for both classes versus conditioning time; $b$ - variation of flotation recovery for both classes versus flotation time; $c$ - variation of flotation recovery for both classes versus $p H ; d-$ variation of flotation recovery for both classes versus oleic acid dosage

bonates at different flotation time. This table also represents the $\mathrm{P}_{2} \mathrm{O}_{5}$ content and flotation recovery for flotation products (floating and flowing). We can see from this table that the optimal flotation time periods recorded for both classes $\mathrm{C} 1$ and $\mathrm{C} 2$ are $8 \mathrm{~min}$ and $6 \mathrm{~min}$, respectively.

From Fig. 2, b, we see an increase in the flotation recovery for both classes with increasing flotation time to reach their maximum at $6 \mathrm{~min}$ and $8 \mathrm{~min}$ for both classes $\mathrm{C} 1$ and $\mathrm{C} 2$, respectively, then a remarkable decrease in class $\mathrm{C} 1$. Indeed, the difference in flotation time for both classes is due to the sequence time of elementary steps during the contact particle-bubble, namely, the particle-bubble collision time, the particlebubble attachment time and the particle-bubble aggre- 
Table 2

Variation of $\mathrm{P}_{2} \mathrm{O}_{5}$ content and flotation recovery $(\mathrm{Re})$ in flotation products of both classes at different flotation time (Tf)

\begin{tabular}{|c|c|c|c|c|c|c|c|c|c|}
\hline \multicolumn{2}{|c|}{ Tf (min) } & \multicolumn{2}{c|}{4} & \multicolumn{2}{c|}{6} & \multicolumn{2}{c|}{10} \\
\hline \multicolumn{2}{|c|}{ Products } & Floating & Flowing & Floating & Flowing & Floating & Flowing & Floating & Flowing \\
\hline \multirow{2}{*}{ Mass (\%) } & $\mathrm{C} 1$ & 13.04 & 86.96 & 14.39 & 85.61 & 15.55 & 84.45 & 14.61 & 85.39 \\
\cline { 2 - 11 } & $\mathrm{C} 2$ & 08.93 & 91.07 & 09.94 & 90.06 & 08.57 & 91.43 & 08.14 & 91.86 \\
\hline \multirow{2}{*}{$\mathrm{P}_{2} \mathrm{O}_{5}(\%)$} & $\mathrm{C} 1$ & 24.65 & 25.25 & 22.17 & 27.72 & 20.19 & 28.97 & 21.62 & 27.81 \\
\cline { 2 - 11 } & $\mathrm{C} 2$ & 26.62 & 28.74 & 22.85 & 30.44 & 25.85 & 28.44 & 27.07 & 28.08 \\
\hline \multirow{2}{*}{$\operatorname{Re}(\%)$} & $\mathrm{C} 1$ & \multicolumn{2}{|c|}{87.25} & 88.15 & 88.63 & & 88.26 \\
\cline { 2 - 10 } & $\mathrm{C} 2$ & \multicolumn{2}{|c|}{91.66} & \multicolumn{2}{c|}{92.35} & \multicolumn{2}{c|}{92.13} & 92.14 \\
\hline
\end{tabular}

gate stability time. As class $\mathrm{C} 1$ is rich in carbonates, so the sequence time of elementary steps will be higher in class $\mathrm{C} 1$ with respect to class $\mathrm{C} 2$.

$\boldsymbol{p H}$. The reverse flotation results obtained for both studied classes as well as the weight recovery yields in depressed phosphate and floated carbonates at different $\mathrm{pH}$ values are given in Table 3 . The latter also represents the $\mathrm{P}_{2} \mathrm{O}_{5}$ content and flotation recovery for flotation products (floating and flowing). We can see from this table that the optimal $\mathrm{pH}$ recorded for both classes $\mathrm{C} 1$ and $\mathrm{C} 2$ is $\mathrm{pH} 9$.

From the curve of flotation recovery for both classes indicated in Fig. 2, c, we note the rising in flotation recovery in class $\mathrm{C} 1$ when the middle $\mathrm{pH}$ rises then a reduction beyond $\mathrm{pH} 9$, mutually in class $\mathrm{C} 2$ whose flota- tion recovery quickly reaches the maximum at $\mathrm{pH} 9$. Selectively, the separation depends on a delicate balance between reagent concentration and $\mathrm{pH}$. Flotation, when possible, is carried out in an alkaline medium, as most collectors are stable under these conditions [11]. The quality of the phosphate concentrate (flowing) improves much in basic medium compared to the acidic medium, since it allows an attachment time reduction and, frequently, more stability of the oleic acid collector.

Oleic acid dosage. Table 4 shows the reverse flotation results corresponding to both studied classes as well as the weight recovery yields in depressed phosphate and floated carbonates at different oleic acid dosage. This table also represents the $\mathrm{P}_{2} \mathrm{O}_{5}$ content and flotation recovery for flotation products (floating and flowing). We

Table 3

Variation of $\mathrm{P}_{2} \mathrm{O}_{5}$ content and flotation recovery $(\mathrm{Re})$ in flotation products of both classes at different $\mathrm{pH}$

\begin{tabular}{|c|c|c|c|c|c|c|c|c|c|}
\hline \multirow{2}{*}{\multicolumn{2}{|c|}{$\begin{array}{c}\mathrm{pH} \\
\text { Products }\end{array}$}} & \multicolumn{2}{|c|}{6} & \multicolumn{2}{|c|}{7.5} & \multicolumn{2}{|c|}{9} & \multicolumn{2}{|c|}{10.5} \\
\hline & & \multirow{2}{*}{$\begin{array}{c}\text { Floating } \\
79.09\end{array}$} & \multirow{2}{*}{$\frac{\text { Flowing }}{20.91}$} & \multirow{2}{*}{$\begin{array}{c}\text { Floating } \\
09.14\end{array}$} & \multirow{2}{*}{$\frac{\text { Flowing }}{90.86}$} & \multirow{2}{*}{$\frac{\text { Floating }}{13.68}$} & \multirow{2}{*}{$\frac{\text { Flowing }}{86.32}$} & \multirow{2}{*}{$\frac{\text { Floating }}{12.64}$} & \multirow{2}{*}{$\frac{\text { Flowing }}{87.36}$} \\
\hline Mass (\%) & $\mathrm{C} 1$ & & & & & & & & \\
\hline & $\mathrm{C} 2$ & 82.09 & 17.91 & 73.10 & 26.90 & 09.54 & 90.46 & 07.54 & 92.46 \\
\hline \multirow[t]{2}{*}{$\mathrm{P}_{2} \mathrm{O}_{5}(\%)$} & $\mathrm{C} 1$ & 25.11 & 23.50 & 22.48 & 25.70 & 14.06 & 28.63 & 21.12 & 27.61 \\
\hline & $\mathrm{C} 2$ & 28.45 & 25.48 & 27.97 & 26.64 & 19.87 & 30.78 & 26.01 & 28.59 \\
\hline \multirow[t]{2}{*}{$\operatorname{Re}(\%)$} & $\mathrm{C} 1$ & \multicolumn{2}{|c|}{19.82} & \multicolumn{2}{|c|}{91.93} & \multicolumn{2}{|c|}{92.79} & \multicolumn{2}{|c|}{90.03} \\
\hline & $\mathrm{C} 2$ & \multicolumn{2}{|c|}{16.34} & \multicolumn{2}{|c|}{25.96} & \multicolumn{2}{|c|}{93.61} & \multicolumn{2}{|c|}{93.10} \\
\hline
\end{tabular}

Table 4

Variation of $\mathrm{P}_{2} \mathrm{O}_{5}$ content and flotation recovery $(\mathrm{Re})$ in flotation products of both classes at different oleic acid dosage (Doa)

\begin{tabular}{|c|c|c|c|c|c|c|c|c|c|}
\hline \multirow{2}{*}{\multicolumn{2}{|c|}{$\frac{\text { Doa }(\mathrm{g} / \mathrm{t})}{\text { Products }}$}} & \multicolumn{2}{|c|}{1500} & \multicolumn{2}{|c|}{2000} & \multicolumn{2}{|c|}{2500} & \multicolumn{2}{|c|}{3000} \\
\hline & & \multirow{2}{*}{$\begin{array}{c}\text { Floating } \\
12.83\end{array}$} & \multirow{2}{*}{$\begin{array}{c}\text { Flowing } \\
87.17\end{array}$} & \multirow{2}{*}{$\begin{array}{c}\text { Floating } \\
13.79\end{array}$} & \multirow{2}{*}{$\begin{array}{c}\text { Flowing } \\
86.21\end{array}$} & \multirow{2}{*}{$\begin{array}{c}\text { Floating } \\
14.63\end{array}$} & \multirow{2}{*}{$\begin{array}{c}\text { Flowing } \\
85.37\end{array}$} & \multirow{2}{*}{$\begin{array}{c}\text { Floating } \\
16.02\end{array}$} & \multirow{2}{*}{$\begin{array}{c}\text { Flowing } \\
83.98\end{array}$} \\
\hline Mass (\%) & $\mathrm{C} 1$ & & & & & & & & \\
\hline & $\mathrm{C} 2$ & 06.91 & 93.09 & 07.61 & 92.39 & 09.86 & 90.14 & 59.54 & 40.46 \\
\hline \multirow[t]{2}{*}{$\mathrm{P}_{2} \mathrm{O}_{5}(\%)$} & $\mathrm{C} 1$ & 22.47 & 26.36 & 20.90 & 27.38 & 16.41 & 28.74 & 24.65 & 27.72 \\
\hline & $\mathrm{C} 2$ & 25.40 & 28.29 & 19.87 & 30.89 & 22.09 & 29.14 & 24.85 & 29.76 \\
\hline \multirow[t]{2}{*}{$\operatorname{Re}(\%)$} & $\mathrm{C} 1$ & \multicolumn{2}{|c|}{88.86} & \multicolumn{2}{|c|}{89.12} & \multicolumn{2}{|c|}{91.09} & \multicolumn{2}{|c|}{85.49} \\
\hline & $\mathrm{C} 2$ & \multicolumn{2}{|c|}{93.74} & \multicolumn{2}{|c|}{94.98} & \multicolumn{2}{|c|}{92.34} & \multicolumn{2}{|c|}{44.86} \\
\hline
\end{tabular}


can see from this table that the optimal oleic acid dosages recorded for both classes $\mathrm{C} 1$ and $\mathrm{C} 2$ are 2500 and $2000 \mathrm{~g} / \mathrm{t}$, respectively.

Histogram of flotation recovery for both classes shown in Fig. 2, $d$, shows a slight rising in flotation recovery for class $\mathrm{C} 2$ depending on the collector dose and regression after $2000 \mathrm{~g} / \mathrm{t}$. There was also a low increase in flotation recovery then a decrease beyond $2500 \mathrm{~g} / \mathrm{t}$ for class $\mathrm{C} 1$.

For collector evaluation, it was observed that the cumulative recoveries for carbonates were low at lower collector dosages. This is because at lower concentrations, the amount of the collector is insufficient to coat and/or react with all the mineral surfaces available and turns them in hydrophobic by leaving most of the valuable minerals unfloated, and are thus lost as final tailings.

Influence of particle size. Table 5 shows the reverse flotation results for both studied classes as well as the weight recovery yields in depressed phosphate and floated carbonates at different optimal parameters (Tc, Tf, $\mathrm{pH}$ and Doa). This table also represents the $\mathrm{P}_{2} \mathrm{O}_{5}$ content and flotation recovery for flotation products (floating and flowing).
Reverse flotation of the natural phosphate ore gives appreciable results compared to the concentration in useful element $\left(\mathrm{P}_{2} \mathrm{O}_{5}\right)$ to raw ore. Indeed, $\mathrm{P}_{2} \mathrm{O}_{5}$ content passed from 26 to $31 \%$ in the flowing and this did not prevent the tendency of fine phosphatic particles to float with carbonates ( $23 \%$ of $\mathrm{P}_{2} \mathrm{O}_{5}$ in the floating). The latter are rich in carbonates and clays, its specific surface area is more important, so a more important reactivity is relative to class $\mathrm{C} 2$, which requires therefore a depression in the second floor with a cationic collector. From Fig. 3 we see that $\mathrm{P}_{2} \mathrm{O}_{5}$ contents are more important in class $\mathrm{C} 2$ than in class $\mathrm{C} 1$, which indicates that the optimal liberation mesh of the phosphate elements separation is contained in class $\mathrm{C} 2$.

The research studies have shown that, in the upper regions of well-drained froths, the drainage rates of coarse particles can differ from those of the finer particles, since they can become trapped in the bubble films more easily. Conversely, coarse particles can become dislodged from the bubbles more easily than fine particles because of their larger mass. The velocity at which coarse particles drain from the froth can also differ from that of finer particles because of interactions between

Table 5

Variation of $\mathrm{P}_{2} \mathrm{O}_{5}$ content and flotation recovery (Re) in flotation products of both classes at the studied optimal parameters

\begin{tabular}{|c|c|c|c|c|c|c|c|c|c|}
\hline \multirow{2}{*}{\multicolumn{2}{|c|}{$\begin{array}{c}\text { Parameters } \\
\text { Products }\end{array}$}} & \multicolumn{2}{|c|}{$\mathrm{Tc}$} & \multicolumn{2}{|c|}{$\mathrm{Tf}$} & \multicolumn{2}{|c|}{$\mathrm{pH}$} & \multicolumn{2}{|c|}{ Doa } \\
\hline & & \multirow{2}{*}{$\begin{array}{c}\text { Floating } \\
16.49\end{array}$} & \multirow{2}{*}{$\begin{array}{c}\text { Flowing } \\
83.51\end{array}$} & \multirow{2}{*}{$\begin{array}{c}\text { Floating } \\
15.55\end{array}$} & \multirow{2}{*}{$\begin{array}{c}\text { Flowing } \\
84.45\end{array}$} & \multirow{2}{*}{$\begin{array}{c}\text { Floating } \\
13.68\end{array}$} & \multirow{2}{*}{$\begin{array}{c}\text { Flowing } \\
86.32\end{array}$} & \multirow{2}{*}{$\begin{array}{c}\text { Floating } \\
14.63\end{array}$} & \multirow{2}{*}{$\begin{array}{c}\text { Flowing } \\
85.37\end{array}$} \\
\hline Mass (\%) & $\mathrm{C} 1$ & & & & & & & & \\
\hline & $\mathrm{C} 2$ & 07.82 & 92.18 & 09.94 & 90.06 & 09.54 & 90.46 & 07.61 & 92.39 \\
\hline \multirow[t]{2}{*}{$\mathrm{P}_{2} \mathrm{O}_{5}(\%)$} & $\mathrm{C} 1$ & 18.79 & 28.76 & 20.19 & 28.97 & 14.06 & 28.63 & 16.41 & 28.74 \\
\hline & $\mathrm{C} 2$ & 18.93 & 30.21 & 22.85 & 30.44 & 19.87 & 30.78 & 19.87 & 30.89 \\
\hline \multirow[t]{2}{*}{$\operatorname{Re}(\%)$} & $\mathrm{C} 1$ & \multicolumn{2}{|c|}{88.57} & \multicolumn{2}{|c|}{88.63} & \multicolumn{2}{|c|}{92.79} & \multicolumn{2}{|c|}{91.09} \\
\hline & $\mathrm{C} 2$ & \multicolumn{2}{|c|}{94.95} & \multicolumn{2}{|c|}{92.35} & \multicolumn{2}{|c|}{93.61} & \multicolumn{2}{|c|}{94.98} \\
\hline
\end{tabular}
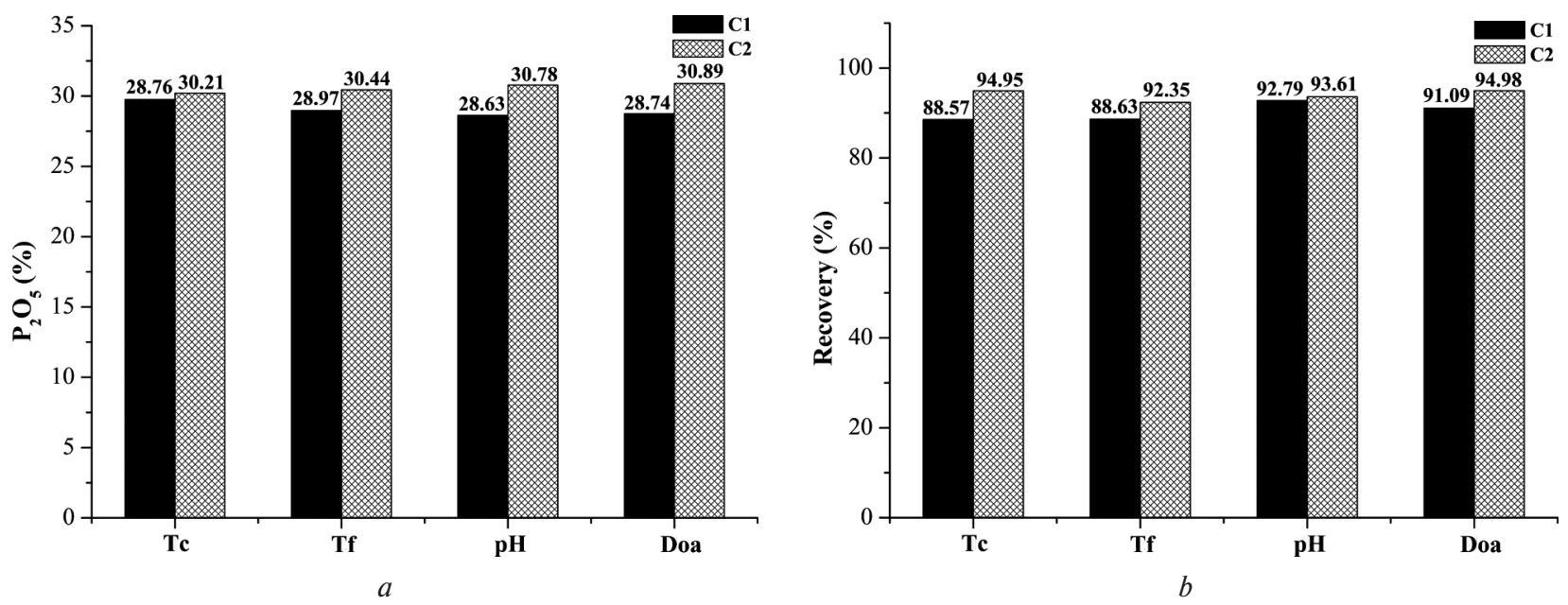

Fig. 3. Variations of $P_{2} O_{5}$ content:

$a$-variation of $P_{2} O_{5}$ content for both classes versus optimal parameters; $b$ - variation of flotation recovery for both classes versus optimal parameters 
the particles and the walls of the plateau borders along which drainage occurs. Under such conditions, the behavior of certain species, influenced by the characteristics of the froth, can obscure the behavior and hence the possible detachment of other species. This is preferred as small bubble size increases inter particular surface area which improves separation by flotation [12].

Characterizations of flotation products. Analysis by $x$-ray diffraction (XRD). The analysis by $\mathrm{x}$-ray diffraction was performed on the flotation products of both classes at the optimal parameters to identify the mineral phases that constitute the inorganic powder and the obtained results are represented by the diffractograms in Fig. 4. According to the obtained x-ray diffractograms, we have noticed discernible differences between the flowings and the floatings. Indeed, the qualitative and quantitative variation of mineralogical species, particularly phosphatic elements and carbonates, perfectly follow the evolution of the enrichment degree and hence we have concluded the following points:

1. A net decrease in the intensity of carbonates characteristic lines in flowing obtained with both classes $\mathrm{Cl}$ and $\mathrm{C} 2$ for the various parameters and its importance in floating.

2. The mineralogical analysis results illustrated by the diffractograms in Fig. 4 show that the flowing is rich in phosphatic elements (fluorapatite, hydroxylapatite, hydroxylapatite carbonate, fluorapatite carbonate) and poor in carbonates (dolomite, calcite), unlike to the floating which is mainly of dolomite with a low quantity of phosphatic elements.

Infrared spectrometry analysis (IR). Infrared analyses are performed on the flotation products for both classes in order to apprehend the evolution of the mineral phases depressed and floated related to the optimal parameters. Infrared spectra (Fig. 5) clearly show the main bands allocated to the phosphatic elements and carbonates, in particular:

1. Larger bands of strong intensity in the flowing than in the floating corresponding to $\mathrm{PO}_{4}^{3-}$ and $\mathrm{PO}_{4}^{2-}$ ions peaks observed at $1047.77 \mathrm{~cm}^{-1}$ (very strong) and $603.13 \mathrm{~cm}^{-1}$ (low), respectively.

2. Intense peak observed at $1429.21 \mathrm{~cm}^{-1}$ characteristic of the apatitic $\mathrm{CO}_{3}^{2-}$ ions is much more intense in the flowing and low in floating.

3. Two peaks observed at 1632.35 and $872.5 \mathrm{~cm}^{-1}$ (low) characteristics of end gangue carbonates is more intense in floating than in flowing.

4. Large band observed at $3444.76 \mathrm{~cm}^{-1}$ (strong) attributed to the $\mathrm{OH}$ groups, greater in the flowing than in the floating, this is bounded either to the constitution water in different mineralogical forms $\left(\mathrm{Ca}_{3}\left(\mathrm{PO}_{4}\right)_{2} \cdot \mathrm{H}_{2} \mathrm{O}\right.$, $\left.\mathrm{CaSO}_{4} \cdot 2 \mathrm{H}_{2} \mathrm{O}, \mathrm{Mg}_{5} \mathrm{Si}_{8} \mathrm{O}_{20}(\mathrm{OH})_{2} \cdot 8 \mathrm{H}_{2} \mathrm{O}\right)$, or then to the presence of hydroxyapatite in strong proportion.

5. The appearance of weak peaks between 2500 and $2600 \mathrm{~cm}^{-1}$ in the characteristical spectrum of class $\mathrm{C} 1$ which are attributed to the elongation of $\mathrm{C}-\mathrm{H}$ and $\mathrm{O}-\mathrm{H}$ bonds, probably related to hydrocarbons constituting the organic matter contained in class $\mathrm{C} 1$.
6. A low peak observed at $2927.89 \mathrm{~cm}^{-1}$ corresponding to $-\mathrm{CH}_{2}-\mathrm{CH}_{3}$, showing the adsorption of the collector used on the phosphatic particles.

In most cases, the intensity of the characteristic peaks of phosphatic elements is clearly more remarkable in the flowing than in the floating. In contrast, the vibration bands attributed to the $\mathrm{CO}_{3}^{2-}$. ions are much more intense in the floating than in the flowing.

Conclusions. Our study focused on the enrichment of the natural phosphate ores of Kef Es Sennoun deposit by reverse flotation. The general method applied for this phosphate ore type consists of the recovery in basic medium using oleic acid collector to float the carbonates, the phosphatic elements being depressed by double tartrate of sodium and potassium and the obtained floating and flowing products are characterized by different analysis techniques.

The physico-chemical and mineralogical analyses results confirmed the major presence of phosphatic elements in the flowing and minor of carbonates, unlike to the floating which is mainly of dolomite with a low quantity of phosphatic elements.

The obtained results in application to both granulometric classes namely class $\mathrm{C} 1$ and $\mathrm{C} 2$, titrate a little more than $30 \%$ in $\mathrm{P}_{2} \mathrm{O}_{5}$ compared to raw sample (26\%), demonstrate the efficiency of the method. $\mathrm{P}_{2} \mathrm{O}_{5}$ contents are more important in class $\mathrm{C} 2$ than in class $\mathrm{C} 1$, which indicates that the optimal liberation mesh of the phosphate elements separation is contained in class $\mathrm{C} 2$. The best obtained results of $\mathrm{P}_{2} \mathrm{O}_{5}$ corresponding to the conditioning and flotation optimal times recorded for both classes are 10 and $8 \mathrm{~min}$ for class $\mathrm{C} 1,7.5$ and $6 \mathrm{~min}$ for class $\mathrm{C} 2$, respectively. The best $\mathrm{pH}$ that corresponds to a higher flotation recovery for both classes is $\mathrm{pH} \mathrm{9,} \mathrm{this}$ allows a reduction of the attachment time and often a more stability of the collector. Flotation by oleic acid collector permits more efficient separation of carbonate-phosphate system in the measurement, the adsorption optimal dosages of collector adsorption on the carbonates are 2500 and $2000 \mathrm{~g} / \mathrm{t}$ for class $\mathrm{C} 1$ and class C2, respectively.

The reverse flotation process developed in the laboratory, applied to carbonated phosphate ores, has shown its good efficiency not only for depressed phosphatic elements in the concentrates, but also for floated carbonates in the flotation wastes. Indeed, it was possible to achieve phosphate concentrate contents of nearly $31 \%$ of $\mathrm{P}_{2} \mathrm{O}_{5}$ with satisfactory recovery (85$95 \%)$.

Acknowledgements. The authors would like to thank the Laboratory of Materials Technology and Process Engineering (LTMGP), University of Bejaia, Algeria and Ministry of Higher Education and Scientific Research of the Algerian government for supporting this research. Special thanks to Dr. Boulanouar MESSAOUDI for his friendly support.

\section{References.}

1. Birken, I., Bertucci, M., Chappelin, J., \& Jorda, E. (2016). Quantification of Impurities, Including Carbonates Speciation for Phosphates Beneficiation by Flota- 

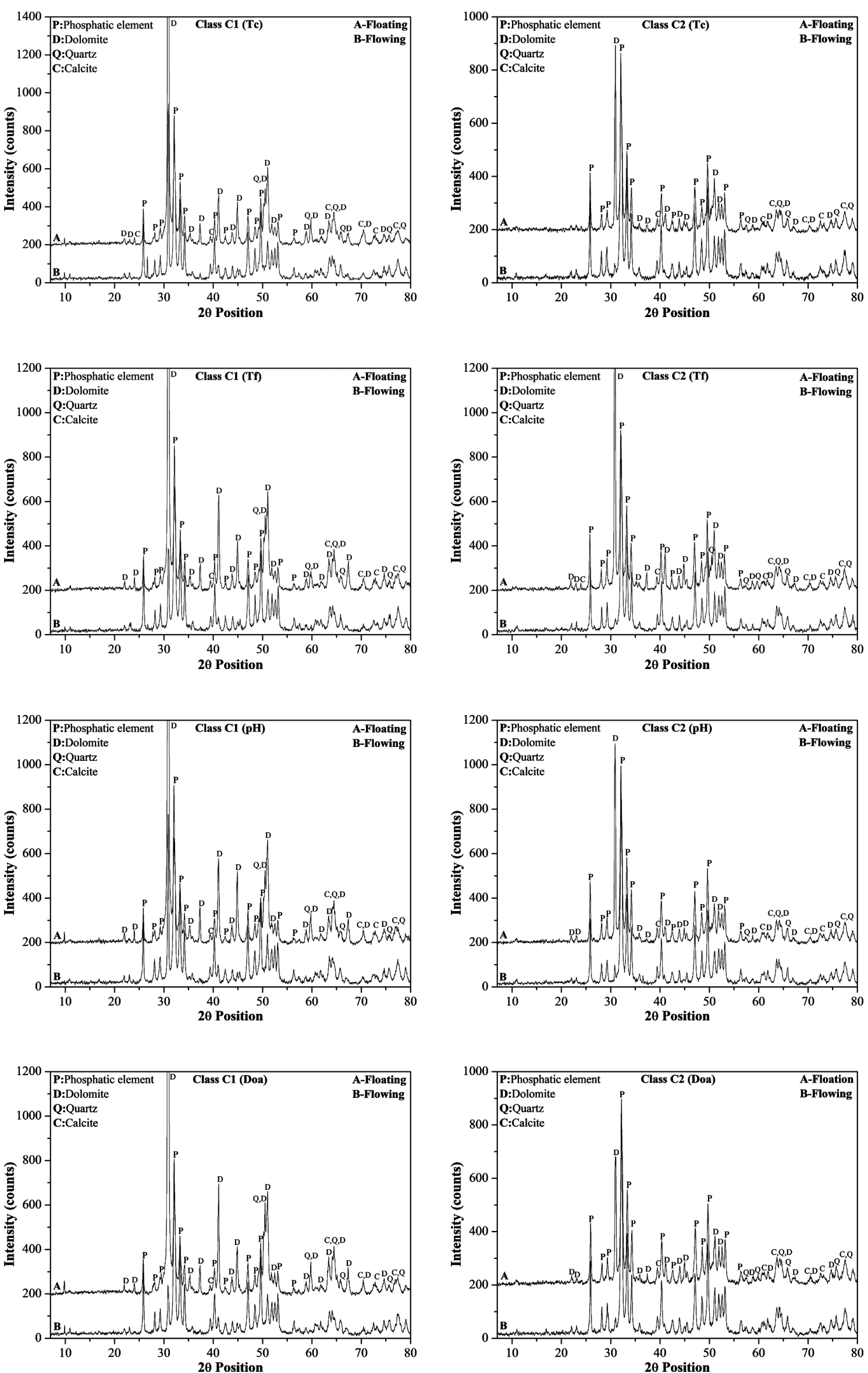

Fig. 4. X-ray diffractograms of the flotation products obtained (floating and flowing) with the studied optimal parameters for both classes $\mathrm{C} 1$ and $\mathrm{C} 2$ 

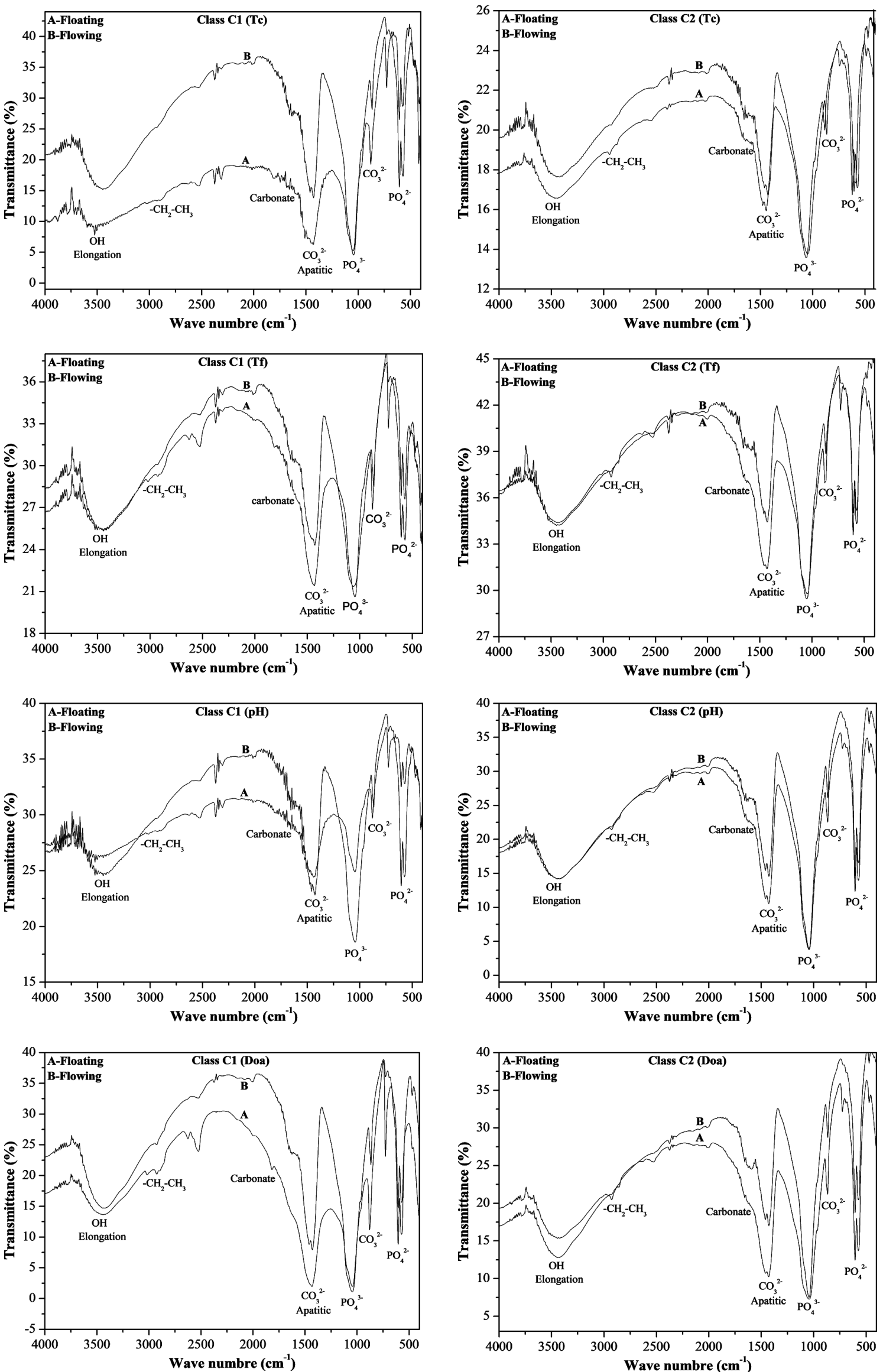

Fig. 5. Infrared spectra of the flotation products obtained (floating and flowing) with the studied optimal parameters for both classes $\mathrm{C} 1$ and $\mathrm{C} 2$ 
tion. Procedia Engineering, 138, 72-84. DOI: 10.1016/j. proeng.2016.02.059.

2. Cao, Q., Cheng, J., Wen, S., Li, C., Bai, S., \& Liu, D. (2015). A mixed collector system for phosphate flotation. Minerals Engineering, 78, 114-121. DOI:10.1016/j. mineng.2015.04.020.

3. Tuo, B., Yang, J., Han, L., Wang, J., \& Yao, Y. (2016). Flotation experimental research of calcareous-siliceous phosphorite. International Journal of Mineral Processing, 146, 10-14. DOI:10.1016/j.minpro.2015.11.006.

4. Han, Y., Han, S., Kim, B., Yang, J., Choi, J., Kim, K., You, K.-S., \& Kim, H. (2018). Flotation separation of quartz from apatite and surface forces in bubble-particle interactions: Role of $\mathrm{pH}$ and cationic amine collector contents. Journal of Industrial and Engineering .Chemistry. 107-115. DOI: 10.1016/j.jiec.2018.09.036.

5. Kou, J., Tao, D., \& Xu, G. (2010). Fatty acid collectors for phosphate flotation and their adsorption behavior using QCM-D. International Journal of Mineral Processing, 95, 1-9. DOI:10.1016/j.minpro.2010.03.001.

6. Gallala, W., Herchi, F., Ali, I.B., Abbassi, L., Gaied, M.E., \& Montacer, M. (2016). Beneficiation of Phosphate Solid Coarse Waste from Redayef (Gafsa Mining Basin) by Grinding and Flotation Techniques. Procedia Engineering, 138, 85-94. DOI:10.1016/j.proeng.2016.02.065.

7. Kupka, N., \& Rudolph, M. (2018). Froth flotation of scheelite - A review. International Journal of Mining Science and Technology, 28, 373-384. DOI:10.1016/j. ijmst.2017.12.001.

8. Medeiros, de A. R. S., \& Baltar, C.A. M. (2018). Importance of collector chain length in flotation of fine particles. Minerals Engineering, 122, 179-184. DOI: 10.1016/j.mineng.2018.03.008.

9. Jovanović, I., Miljanović, I., \& Jovanović, T. (2015). Soft computing-based modeling of flotation processes Areview. Minerals Engineering, 84, 34-63. DOI:10.1016/j. mineng.2015.09.020.

10. Barrozo, M.A.S., \& Lobato, F.S. (2016). Multiobjective optimization of column flotation of an igneous phosphate ore. International Journal of Mineral Processing, 146, 82-89. DOI:10.1016/j.minpro.2015.12.001.

11. Muzenda, E., Member, IAENG., Ayo, S.A., Ambali, S. A., \& Freeman, N. (2011, October 19-21). Effect of $\mathrm{pH}$ on the recovery and grade of base metal sulphides (PGMs) by flotation. Proceedings of the World Congress on Engineering and Computer Science (WCECS), San Francisco, USA, 2011. DOI:10.1007/978-94-007-47869_19.

12. Mukherjee, S., Mukhopadhyay, S., Pariatamby, A., Hashim, M.A., Redzwan, G., \& Sen Gupta, B. (2015). Optimization of pulp fibre removal by flotation using colloidal gas aphrons generated from a natural surfactant. Journal of the Taiwan Institute of Chemical Engineers, 53, 15-21. DOI:10.1016/j. jtice.2015.02.037.

\section{Оптимізація флотаційних параметрів на збагаченнях фосфатної руди (Алжир)}

\author{
Ф. Айт Мерзег ${ }^{1,2}$, Н. Беззі ${ }^{1}$
}

1 - Лабораторія матеріалознавства й технології виробництва, Університет імені Абдеррахмана Миру, м. Беджая, Алжир

2 - Відділ аналізу та технологічного розвитку з питань навколишнього середовища, Центр наукового та технічного розвитку в галузі фізико-хімічного аналізу ВР 384 , м. Бу-Ісмаїл, Алжир

Мета. Обробка алжирської природного фосфатної руди з родовища Джебель Онк за допомогою процесу флотації із застосуванням флотаційної камери виробництва Motso Mineral Industries (США). Дана фосфатна руда містить карбонат і силікатні домішки, що негативно впливає на коефіцієнт в'язкості фосфорної кислоти у процесі її виробництва.

Методика. Порядок проведення експерименту заснований на двох аспектах: 1) попередні виробничі підготовчі роботи за всіма процеами: дроблення, усереднення, квартування, просіювання, за якими йдуть відсів і дешламація; 2) підготовка реагентів різної якості з подальшим подрібненням, кондиціонуванням і флотацією.

Результати. Ми можемо зробити висновок про те, що зворотна флотація є найкращою та сприяє економічно ефективному виходу продукції. Процес флотації показав свою ефективність пригніченням фосфатних елементів при отриманні фосфатних концентратів, а також переходом у пінний продукт карбонатів, що є відходами флотації. Дійсно, вдалося отримати фосфатний концентрат із вмістом $31 \% \mathrm{P}_{2} \mathrm{O}_{5}$ при задовільному вилученні (85-95\%).

Наукова новизна. Флотаційні дослідження застосовуються для обох гранулометричних класів С1 (40-250 мКм) і С2 (250-500 мКм), задля отримання концентрату, що містить близько $30 \% \mathrm{P}_{2} \mathrm{O}_{5}$ у порівнянні із сировиною (26 \%), що дозволило досягти вилучення продукту (85-95 \%). Кращі результати були отримані при наступних оптимальних умовах: час кондиціонування та флотації 10 і 8 хв для класу C1, тоді як для класу С2 було визначено 7,5 і 6 хв відповідно. Кращим показником рН, що відповідає більш високому вилученню при флотації для обох класів, є 9. Оптимальна кількість для адсорбції олеїнової кислоти на елементах порожніх порід становить 2500 і 2000 г/т. для класів С1 і С2 відповідно.

Практична значимість. У роботі із продуктами флотації були застосовані різні аналітичні методи (дифракції рентгенівських променів, рентгенівська флуоресценція, інфрачервона спектроскопія на основі перетворення Фур'є), а саме: до камерного продукту (фосфатного концентрату) і пінного продукту (карбонатних відходів), що дозволяє поновому підходити до оптимізації переробки та збагачення фосфатних руд, а також звернути особливу увагу на дотримання режиму флотації з метою отримання найкращої якості фосфатного концентрату.

Ключові слова: природний фосфат, карбонат, флотація, оптимізація, Джебель Онк 


\section{Оптимизация флотационных параметров на обогащениях фосфатной руды (Алжир)}

$$
\text { Ф. Айт Мерзег }{ }^{1,2}, \text { Н. Беззи }{ }^{1}
$$

1 - Лаборатория материаловедения и технологии производства, Университет имени Абдеррахмана Мира, г. Беджая, Алжир

2 - Отдел анализа и технологического развития по вопросам окружающей среды, Центр научного и технического развития в области физико-химического анализа ВР 384, г. Бу-Исмаил, Алжир

Цель. Обработка алжирской природной фосфатной руды с месторождения Джебель Онк с помощью процесса флотации с применением флотационной камеры производства Motso Mineral Industries (США). Данная фосфатная руда содержит карбонат и силикатные примеси, что негативно влияет на коэффициент вязкости фосфорной кислоты в процессе ее производства.

Методика. Порядок проведения эксперимента основан на двух аспектах: 1) предварительные производственные подготовительные работы по всем процессам: дробление, усреднение, квартование, просеивание, за которыми следуют отсев и дешламация; 2) подготовка реагентов разного качества с последующим измельчением, кондиционированием и флотацией.

Результаты. Мы можем сделать вывод о том, что обратная флотация является наиболее предпочтительной и способствует экономически эффективному выходу продукции. Процесс флотации показал свою эффективность подавлением фосфатных элементов при получении фосфатных концентратов, а также переходом в пенный продукт карбонатов, являющихся отходами флотации. Действи- тельно, удалось получить фосфатный концентрат с содержанием $31 \% \mathrm{P}_{2} \mathrm{O}_{5}$ при удовлетворительном извлечении (85-95\%).

Научная новизна. Флотационные исследования применяются для обоих гранулометрических классов С1 (40-250 мКм) и С2 (250-500 мКм), для получения концентрата, содержащего около $30 \% \mathrm{P}_{2} \mathrm{O}_{5}$ по сравнению с сырьем (26\%), что позволило достичь извлечения продукта (85-95 \%). Лучшие результаты были получены при следующих оптимальных условиях: время кондиционирования и флотации 10 и 8 мин для класса $\mathrm{C} 1$, тогда как для класса С2 было определено 7,5 и 6 мин соответственно. Лучшим показателем рН, который соответствует более высокому извлечению при флотации для обоих классов, является 9. Оптимальное количество для адсорбции олеиновой кислоты на элементах пустых пород составляет 2500 и 2000 г/т для классов С1 и С2 соответственно.

Практическая значимость. В работе с продуктами флотации были применены различные аналитические методы (дифракции рентгеновских лучей, рентгеновская флуоресценция, инфракрасная спектроскопия на основе преобразования Фурье), а именно: к камерному продукту (фосфатному концентрату) и пенному продукту (карбонатным отходам), что позволяет по-новому подходить к оптимизации переработки и обогащению фосфатных руд, а также обратить особое внимание на соблюдение режима флотации с целью получения наилучшего качества фосфатного концентрата.

Ключевые слова: природный фосфат, карбонат, флотация, оптимизация, Джебель Онк

Рекомендовано до публікації Абделазіз Ідрес. Дата надходження рукопису 27.02.18. 